\title{
PENDAMPINGAN PENANGANAN CEDERA PADA ANAK \\ USIA SEKOLAH DI SEKOLAH BERBASIS ALAM
}

\section{THE ASSISTANCE OF INJURY MANAGEMENT ON SCHOOL AGE CHILDREN IN THE NATURE BASED SCHOOL}

\author{
Erma Wahyu Mashfufa ${ }^{1}$, Nur Aini ${ }^{2}$, Lilis Setyowati ${ }^{3}$, Ollyvia Freeska DM ${ }^{4}$ \\ 1,2,3,4 Program Studi Ilmu Keperawatan Fakultas Ilmu Kesehatan UMM, Indonesia \\ Email : erma@umm.ac.id
}

\begin{abstract}
ABSTRAK
Pendahuluan : Sekolah berbasis alam sangat banyak diminati masyarakat saat ini, salah satu alasan bersekolah di sekolah alam adalah tidak akan membuat jenuh putra-putri mereka karena hanya berdiam didalam kelas. Sekolah alam memang memberikan banyak manfaat bagi perkembangan anak, namun di sisi lain juga ada permasalahan yang dihadapi yaitu anak berisiko mengalami cedera. Hal ini disebabkan karena banyaknya kegiatan outdoor, anak memiliki rasa ingin tahu yang besar, dan banyak melibatkan aktifitas motorik. Oleh karena itu perlu adanya pendampingan bagi guru mengenai cedera dan penanganan cedera yang terjadi pada anak usia sekolah.

Metode : Setelah dilaksanakan kegiatan pendampingan berupa penyuluhan dan praktik secara langsung oleh tim pengabdian selama kurun waktu \pm 8 bulan, mitra mengetahui penanganan cedera pada anak dan mampu mempraktikkan tindakan penanganan. Selain itu juga dilakukan pre-test dan post-test menggunakan kuesioner untuk mengetahui tingkat pengetahuan guru pendamping.

Hasil : Kegiatan pengabdian masyarakat dilaksanakan pada guru dan petugas UKS MI BAIPAS, di Jl. Manunggal, Sudimoro Utara No. 7A Malang. Kegiatan diikuti oleh 10 peserta. Tahapan kegiatan pengabdian berupa pemberian pre test dilanjutkan pemberian penyuluhan tentang penanganan cedera pada anak dan demonstrasi pemakaian alat-alat P3K dan Tindakan penanganan cedera. Kegiatan dapat dilaksanakan dengan baik hanya saja karena siswa sedang libur maka praktik dilakukan kepada sesama peserta.

Pembahasan : sebagian besar guru pendamping memiliki pengetahuan yang kurang tentang penganan cedera yang sering dialami oleh anak. Rata-rata tidak mengetahui cara penganan luka tusuk, luka bakar, sprain dan strain. Pengetahuan yang sudah baik adalah ciri cedera, faktor resiko dan penanganan tersedak. Sedangkan dari aspek perilaku, semua guru pendamping belum pernah melakukan pemeriksaan dasar cedera dan menggunakan peralatan penanganan cedera. Kegiatan ini membawa dampak positif bagi mitra yaitu mereka mendapatkan pengetahuan dan pengalaman baru yang selanjutnya bisa mereka aplikasikan untuk menjaga kesehatan anak didik. Pertolongan pertama pada cedera dapat meminimalisir kecacatan atau cedera lebih dalam pada anak.
\end{abstract}

Kata kunci : penanganan cedera, anak usia sekolah 
Pendahuluan

Sekolah berbasis alam sangat banyak diminati masyarakat saat ini, salah satu alasan bersekolah di sekolah alam adalah tidak akan membuat jenuh putraputri mereka karena hanya berdiam didalam kelas. Sekolah alam memang memberikan banyak manfaat bagi perkembangan anak, namun di sisi lain juga ada permasalahan yang dihadapi yaitu anak berisiko mengalami cedera. Hal ini disebabkan karena banyaknya kegiatan outdoor, anak memiliki rasa ingin tahu yang besar, dan banyak bergerak/aktifitas motorik. Hutasoit \& Widowati (2017), siswa sekolah dasar adalah kelompok usia yang masih mempunyai keinginan untuk selalu bergerak karena pada masa tersebut anak mempunyai kelebihan energi sehingga disalurkan melalui bergerak, keinginan untuk mengetahui hal-hal baru yang berada di lingkungan dan merupakan masa pertumbuhan dan perkembangan.

Salah satu contoh sekolah alam yang ada di Malang adalah MI Baipas Malang, yang dibuka pada tahun ajaran 2017 - 2018. Walaupun terbilang masih baru, tetapi kegiatan para santri sangat padat. Saat ini MI Baipas memili 15 guru dan jumlah siswa MI Baipas merupakan sekolah alam berbasis Al-Quran. Sistem sekolah adalah fullday dengan fasilitas perkebunan, peternakan seperti kandang kelinci, kolam ikan, kebun, perikanan organik, dan tempat pengolahan sampah dan sebagainya. Pembelajaran lebih menekankan kegiatan belajar outdoor. Informasi yang didapatkan dari Guru MI BAIPAS, seringkali terjadi cedera pada anak seperti terpeleset, jatuh bahkan pernah ada anak yang kena paku. Permasalahan lain yang juga dialami oleh mitra adalah guru - guru belum mengetahui cara penanganan cedera.

Oleh karena itu perlu adanya pendampingan bagi guru mengenai cedera dan penanganan cedera yang terjadi pada anak usia sekolah. Penanganan cedera yang diberikan adalah penanganan cedera dasar berupa tindakan pertolongan pertama pada cedera yang sering dialami anak dan telah tim sesuaikan dengan kondisi lingkungan sekolah yang berbasis alam, yaitu : perdarahan, pingsan, keseleo, jatuh, tersedak, digigit serangga, alergi serbuk bunga, iritasi pada mata serta basic life support pada anak.

\section{Metode}

Melakukan identifikasi permasalahan yang dihadapi oleh mitra terkait dengan penanganan cedera pada anak sekolah. Kedua, pendampingan dan pelatihan penanganan cedera pada anak sekolah. Ketiga, melengkapi sarana atau peralatan penanganan cedera pada anak sekolah. Keempat, Melaporkan segala aktifitas yang dilakukan selama proses pelatihan. Kelima, pemberian kuesioner untuk mengetahui 
pengetahuan guru pendamping tentang penanganan cedera pada anak (pre-test dan post-test).

\section{Hasil}

Kegiatan pengabdian masyarakat dilaksanakan pada guru dan petugas UKS MI BAIPAS, di Jl. Manunggal, Sudimoro Utara No. 7A Malang. Kegiatan diikuti oleh 10 peserta. Lebih detailnya, rincian kegiatan yang telah dilaksanakan dapat dilihat pada tabel di bawah ini :

Tabel 5.1 Rincian Kegiatan dan

\section{Pelaksanaan Kegiatan IbM}

\begin{tabular}{|c|c|c|}
\hline No & Rencana & Pelaksanaan \\
\hline 1 & Persiapan & $\begin{array}{l}\text { Koordinasi dengan mitra untuk } \\
\text { jadwal pelaksanaan kegiatan }\end{array}$ \\
\hline 2 & Proses & $\begin{array}{l}\text { 1. Pemberian pre test } \\
\text { 2. Pemberian penyuluhan tentang } \\
\text { penanganan cedera pada anak } \\
\text { 3. Demonstrasi pemakaian alat- } \\
\text { alat P3K dan Tindakan } \\
\text { penanganan cedera }\end{array}$ \\
\hline 3 & Evaluasi & $\begin{array}{l}\text { 1. Redemonstrasi pemakaian } \\
\text { alat-alat P3K dan Tindakan } \\
\text { penanganan cedera oleh } \\
\text { peserta } \\
\text { 2. Pemberian post test }\end{array}$ \\
\hline 4 & Reevaluasi & $\begin{array}{l}\text { Melakukan evaluasi kembali hasil } \\
\text { kegiatan }\end{array}$ \\
\hline 5 & $\begin{array}{l}\text { Penyusunan } \\
\text { Laporan }\end{array}$ & $\begin{array}{l}\text { Pelaporan kemajuan hasil } \\
\text { kegiatan }\end{array}$ \\
\hline
\end{tabular}

sebagian besar mitra memiliki pengetahuan yang kurang tentang penganan cedera yang sering dialami oleh anak. Rata-rata responden tidak mengetahui cara penganan luka tusuk, luka bakar, sprain dan strain. Pengetahuan yang sudah baik adalah ciri cedera, faktor resiko dan penanganan tersedak. Sedangkan dari aspek perilaku, semua mitra belum pernah melakukan pemeriksaan dasar cedera dan menggunakan peralatan penanganan cedera.

Kegiatan ini membawa dampak positif bagi mitra yaitu mereka mendapatkan pengetahuan dan pengalaman baru yang selanjutnya bisa mereka aplikasikan untuk menjaga kesehatan anak didik. Pertolongan pertama pada cedera dapat meminimalisir kecacatan atau cedera lebih dalam pada anak.

\section{Kesimpulan}

Masalah utama yang dialami oleh mitra adalah penanganan cedera pada anak serta cara menggunakan peralatan $\mathrm{P} 3 \mathrm{~K}$ dengan baik dan melakukan pemeriksaan Kesehatan sederhana. Setelah dilakukan kegiatan penyuluhan dan praktik penanganan pertama pada cedera serta penggunaan alat-alatnya, akhirnya sekarang mereka mengetahui dan bisa melakukan secara mandiri. Dengan mengetahui cara penanganan pertama cedera pada anak diharapkan mampu menurunkan angka kecacatan akibat cedera di sekolah.

\section{DAFTAR PUSTAKA}

Ball, Jane W., Ruth C. Bindler, et all. 2017. Principles of Pediatric Nursing: Caring for Children 7th Edition. USA : Pearson

Hutasoit, F. E., \& Widowati, E. (2017). Gambaran Penerapan Safety Education (Pendidikan Keselamatan) di Sekolah Dasar. Jurnal of Health 
Education, 2(1), 66-72.

Global Children's Fund. 2003. Child Safety and Abuse Prevention Programs. https//: www. first-aid for burns: treating burn injuries in kids (keepyourchildsafe.org)

Piazza, Gina M. 2017. First Aid Fast for Babies and Children: Emergency Procedures for all Parents and Caregivers. UK : DK Publishing

Potter, P. A., \& Perry, A. G. (2016). Fundamentals of Nursing 9th Edition. USA : Elsevier
Purwoko. (2006). Pertolongan Pertama dan RJP Pada Anak. Edisi 4. Jakarta : Arcan.

Sari, I. L. (2011). Sekolah Alam di Surakarta, Sebagai Wadah Pendidikan Anak Bagi Masyarakat Golongan Menengah ke Bawah. Universitas Sebelas Maret Surakarta.

Marilyn Hockenberry Cheryl Rodgers David Wilson. 2016. Wong's Essentials of Pediatric Nursing, 10th Edition. USA : Elsevier

Widjaja. 2002. Mengatasi Diare dan Keracunan pada Balita. Jakarta : Kawan Pustaka. 